\title{
Feminine Writings: Between Representations of Past and Present Femininity
}

\author{
Priscila Kaufmann Corrêa \\ Secretaria de Educação de São Paulo, São Paulo (SP), Brazil
}

\begin{abstract}
The writers of this study are the Countess de Ségur, Louisa May Alcott and Maria Clarice Marinho Villac, from France, the United States and Brazil, respectively. It's possible to identify a connection in their life trajectories-aristocratic and bourgeois families-and the ability to write their books. These publications address a specific audience, composed of children and young people, especially females.

The representation of femininity in the narratives is related to the representation of family and religiosity, since it is up to the family to guide the girls in moral terms and this question is quite highlighted by religion. Analyzing the representation of femininity is due to the fact that the main books of female writers bring female protagonists, who exhibit a rebellious and mischievous behavior, which is observed and guided by adults.

The representations of femininity is still valued and legitimized. For this reason, the narratives continue to be published and adapted to other languages, bringing to light these representations that remain until the 21 st century in new clothing and updated vocabulary. Some adaptations for the Portuguese will also be analyzed, trying to identify longevity the works of these writers and their meaning in some epochs.
\end{abstract}

Keywords: feminine writings, children's literature, representations of femininity, childhood, family, education, religion

\section{Initial Considerations}

At a time when women have their rights questioned, although there is still much to be achieved, representations of femininity permeate different spaces and can be defended or rejected. Analyzing the representations of femininity in children's books is one of the objectives of this work. Femininity is present not only in the text, but also in the images of girls and young women, who complement the narrative. Illustrations and narratives bring out the aspects of femininity. How are these girls and young women? What are the scenarios in which the stories take place? What is expected of these girls and young women? These questions will be addressed throughout the text.

\section{Connected Life Stories}

The representations of femininity continue to be valued and legitimized until our times. For this reason, the narratives continue to be published and adapted to other languages, bringing to light these representations that remain until the 21 st century in new clothing and updated vocabulary.

The writers analyzed here have their life histories connected not only by the longevity of their works, but also by familiar factors and social circulation. There are circumstances that allowed them to enter the

Priscila Kaufmann Corrêa, Ph.D., Kindergarten Teacher in Secretaria de Educação de São Paulo, São Paulo (SP), Brazil. 
publishing market, which expanded at the time, and meet a claim for children's books. These should bring a strong moral appeal in their stories, to guide the small readers through the text.

Each one of the writers was born in different countries, with varied family experiences that allowed them to have access to reading and writing, fundamental to enter the scope of the literature. The Countess of Ségur was born in Russia and married in France, where she resides. Her husband introduced her to publisher Louis Hachette, who sought children's literature writers for his collection to be sold at the train stations. Louisa May Alcott was born in the United States of America, always close to her parents and working to help them. In addition to being governess, seamstress, and teacher, she began to write and gained fame with it. Maria Clarice Marinho Villac, in turn, was born in Itu (São Paulo in Brazil) and studied at the Colégio Progresso Campineiro, a place that marked her childhood and about which she wrote later.

The Countess of Ségur, Louisa May Alcott, and Maria Clarice Marinho Villac were encouraged to read and learned to compose texts, and they liked to tell stories to their relatives. The Countess of Ségur as early as her childhood told stories and continued to do so during her motherhood. Louisa May Alcott composed and performed plays with her sisters, as well as writing poems and short stories. Maria Clarice Marinho Villac composed texts during the school trajectory and counted the troublemaker of childhood to her children and nephews.

Members of the elite, whether aristocratic, in the case of the Countess of Ségur, aristocratic-bourgeois like Louisa May Alcott, or aristocratic-patriarchal like Maria Clarice Marinho Villac, they had the possibility of entering the world of writing and reading, being stimulated by the family. This circle of relationships was essential so that they could meet publishers who were willing to publish their books. With the emergence of the publishing market, they found their place among children's and youth books. Here the books of the Countess of Ségur (of France) composed by Les Petites Filles Modéles (The Little Model Girls) (1858), Les Malheurs de Sophie (The Misfortunes of Sophie) (1858), and Les Vacances (The Holidays) (1859) are analyzed. The books of Louisa May Alcott (USA) are Little Women (1868) and Good Wives or Little Women Part 2 (1869). Maria Clarice Marinho Villac (Brazil), on the other hand, published Clarita da pá Virada (Rebel Clarita) (1939) and Clarita no Colégio (Clarita at the School) (1945).

The books had a great reach, especially those of the Countess of Ségur and Louisa May Alcott, who had adapted versions comic books, musicals, animes, and e-books. Maria Clarice Marinho Villac's books have elements common to other writers' books, such as a narrative of Brazilian scenarios and a colloquial language that surrounds and is closer to the children's reader. For this reason, the books of the Brazilian writer were included in the study.

Within all the narratives are elements about the expectations with regard to childhood and especially of girls, their ways of behaving and obeying. Such representations bring images and symbols of what is expected of childhood in its relationship with the family, with the education and religiosity that guides it in its life trajectory.

\section{The Representations in the Works}

The representation is present through the symbolic images and networks that permeate the narrative discourses. Thus in the speeches of the books, the representation of childhood, family, religiosity, and education are found. 
The representations of the social world thus constructed, while aspiring to the universality of a diagnosis based on reason, are always determined by the group interests that forge them. Hence, for each case, the necessary relationship of the speeches delivered with the position of those who use them.

Social perceptions are by no means neutral: they produce strategies and practices (social, scholastic, political) that tend to impose an authority at the expense of others, who are neglected by it, to legitimize a reforming project or justify it for the individuals themselves, their choices and behaviors. (Chartier, 2002a, p. 17)

The representation aims to act on the subjectivity of the individual so that he accepts the social organization and its projects. There is a set of forces around representations, since they are constructed by a group or community that assists in the constitution of their own social identity and, at the same time, presents and diffuses them among the groups or communities that can identify, resist, or reject such representations.

In books, the representation is present in the discourses, presenting images, and symbols of it. It is also important, from the historical point of view, that such representations are perceived in their singularity, in a contextualized way, avoiding anachronisms. Although femininity is present in the books, it is a femininity of a certain time, which cannot be interpreted as current. Even if it is widespread today, it is a feminism different from the contemporary.

Within the texts themselves, there are layers of representations that bring different relationships between childhood, family, religiosity, and education. The works themselves bring representations that do not refer to a single group or community in that context, but may represent several social ensembles or be incorporated into their discourses.

As regards the illustrations, each of the works has different illustrators, with a varied amount of images in each book. Les Malheurs de Sophie has 48 pictures drawn by Horace Castelli ${ }^{1}$, Les Petites Filles Modèles had 20 Bertall $^{2}$ illustrations, and Les Vacances had 40 illustrations, also by Bertall.

Loiusa May Alcott had her first youth-oriented issue titled Little Women or Meg, Jo, Beth and Amy, with four illustrations by May Alcott, sister of the writer. The text of the second part of Little Women, which was called Good Wives, was later put together in one volume by the Roberts Brothers ${ }^{3}$. This edition dated from 1880 and has 200 illustrations of Frank Thayer Merrill ${ }^{4}$, already with the sequence of Good Wives.

Maria Clarice Marinho Villac became a successful writer from the 1930s to the 1950s. In publishing her works at a time when a demand for children's books was identified, Maria Clarice seemed to be aware that her stories could be divulged. He received nominations from the publishers to print the originals and hired an illustrator to make his books more eye-catching.

\footnotetext{
${ }^{1}$ Horace Castelli drew inspiration from illustrators such as Achille Devéria and Gustave Doré, collaborating with illustrations for such publications as La semaine des familles, Lahure, and the Hachette publishing house, in which he collaborated with illustrations from the books of the Countess of Ségur. Text available on the Internet via: http://www.ricochet-jeunes.org/auteurs/recherche/576-horace-castelli.

2 Bertall is the pseudonym of Albert Amoux, who graduated in drawing working in the atelier of Drolling. He worked for publisher Barba, illustrating the books of Paul de Kock and Cooper, as well as Balzac's La Comédie Humaine (The Human Comedy). He made illustrations for Hachette's books too, including those of the Countess of Ségur.

3 The publisher Roberts Brothers was created in 1857 by Austin J. Roberts and served until 1898 when it was acquired by Little, Brown \& Co. The company was established in 1837 and during the twentieth century joined the Time Warner Book Group. In 2006, the Time Warner Book Group was sold to the French-based Hachette livre, which maintains the publications of Little, Brown \& Co. The publisher Roberts Brothers, who first published the books of Louisa May Alcott, had great success in the sale of children's books, which soon had to be reprinted. The author retained the copyright on these books, ensuring a financial income over the course of her life.

4 There is little information about this illustrator, who stood out in Little Women's illustration.
} 
The first edition of Clarita da pá Virada, from 1939, for example, had illustrations colored on rolled paper. The first edition of Clarita no Colégio, from 1945, had illustrations throughout the text, without differentiated leaves. The illustrations were commissioned by Maria Clarice to the cartoonist Manolo, a caricaturist from Campinas who worked in different periodicals. These are images that seek to be faithful to the photographs presented by the writer. Clarita da pá Virada has 43 illustrations, with seven colored images, and Clarita no Colégio has 17 illustrations, a much smaller number.

In these discourses, the family representation is directly linked to that of childhood, when guiding the movements and activities of children. The images and symbols of the families represented in the publications, both in the text and in the illustrations, indicate the models considered desirable and those that should be rejected.

The constitution of these families in each of the books presents different configurations. The families in the Countess of Ségur's publications are diverse. In Les Malheurs de Sophie, she is made up of Sophie's parents, nanny, and cousin Paul. In Les Petites Filles Modèles, there is the mother of Camille and Madeleine, the exemplary girls, to whom Marguerite, her mother, and the nanny are united. Sophie reappears in this book with her stepmother, but ends up being taken care of by the mother of Camille and Madeleine. Already in Les Vacances, there is the family of the four girls and the two mothers, both widows, besides the parents of Léon and Jean and the parents of Jacques, the cousins of Camille and Madeleine. These are aristocratic families that can ensure a comfortable life for the children.

Little Women presents a family of characteristics closest to the bourgeois organization, composed of four sisters, their mother, and their nanny. The father is distant, as chaplain of the Civil War, returning to the end of the first part of the book. In the second part of the book, three sisters end up marrying and building their own family from the teachings of their parents, especially their mother.

Maria Clarice Marinho Villac presents a family closer to the patriarchal organization in Clarita da pá Virada, with her maternal grandparents, her parents, uncles, and many employees. The latter is part of the family, as they are present in the activities of the other members and interfere in their activities.

In the books of the three writers, there are female protagonists: Sophie, in the books of the Countess of Ségur; Josephine, of Louisa May Alcott, and Clarita, of Maria Clarice Marinho Villac. The question of behavior is always put in check in all narratives. Children are expected to know how to behave and there are adult figures who offer advice and guidance. However, there are layers of representation that, while bringing the way certain social groups deal with childhood, show that there are other ways of dealing with it as a counterpoint to a representation taken as ideal. Roger Chartier (2002b) pointed out that it is necessary to "treat discourses in their discontinuity and disagreement" (p. 77), since discursive organizations have their own logic.

In the books of the Countess of Ségur, the protagonist Sophie is inventive and naive. Once she received a wax doll from her father and soon wanted to play with her. She thought the doll was very white and wanted to leave it in the sun to improve her skin. Her mother worries about guiding her after the doll has lost her eyes:

\section{MADAME DE RÉAN}

I told you, Sophie, that a disaster would happen to your doll if you persisted in leaving it in the sun. Fortunately, the figure and arms did not have time to melt. Come on, do not cry, I'm a skilled doctor, I can recover my eyes from your wax doll. (Ségur, 1880, p. 9)

The mother unleashes the doll to retrieve the glass eyes and glue with a candle on the doll's face. The hand shows that Sophie's attitude of leaving the doll in the sun is not adequate, but she looks for ways to fix it. Like 
a present mother, she is attentive to her daughter's movements, but not to give her freedom, but hoping that her behavior would be different. The fact that the mother knows how to sew is a feminine attitude and she knows how to use the candle for manual activities.

In her mother's posture, which catches Sophie's attention, there is a clash between the discipline indicated by her parents and the freedom Sophie finds to carry out her experiences. Throughout Les Malheurs de Sophie, the child acknowledges that she has erred and with each chapter she discovers how she ought to behave, since her experiences are not successful.

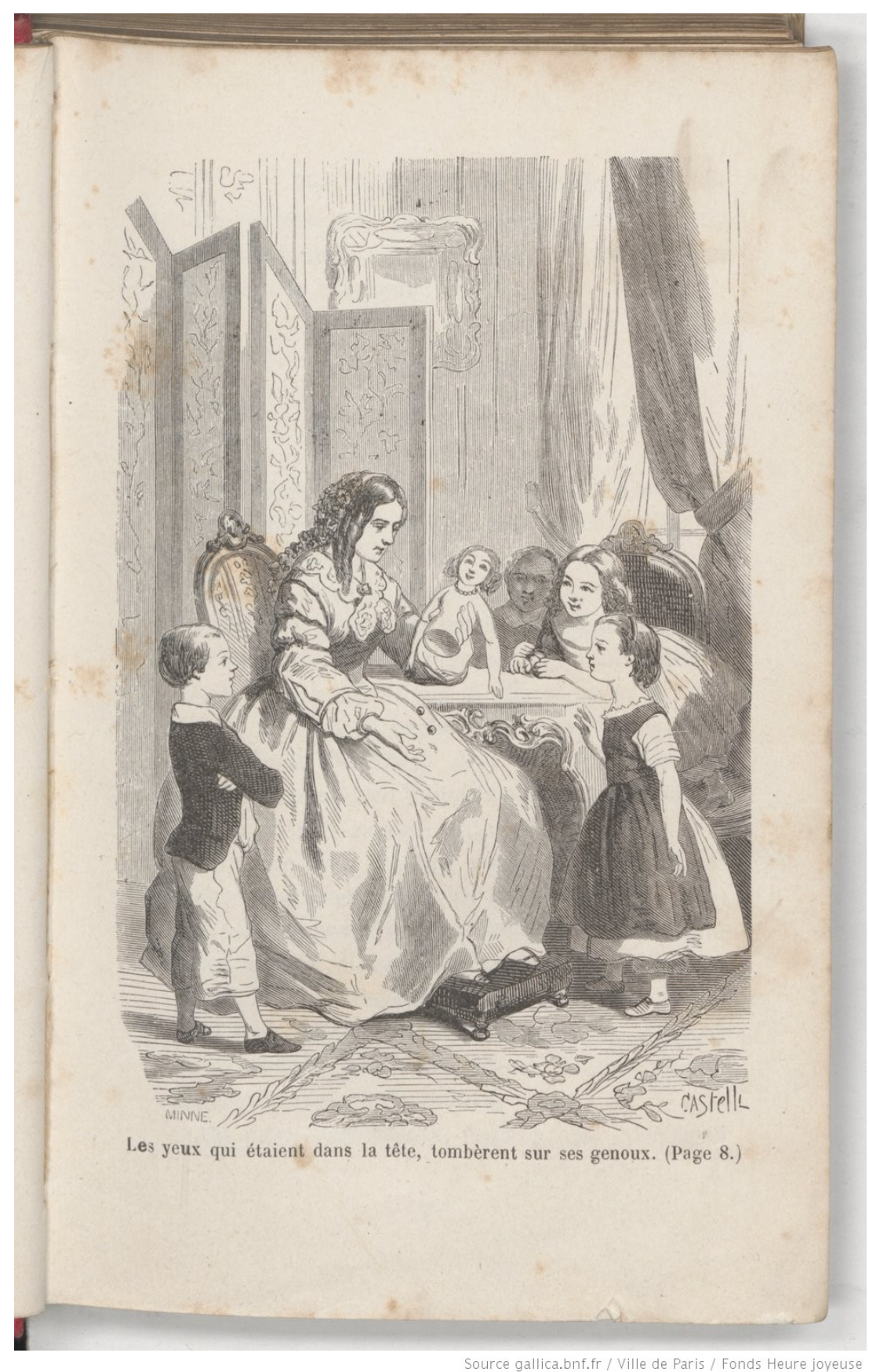

Figure 1. Les Malheurs de Sophie, 1880, p. 23, by Horace Castelli. 
In analyzing the illustration in book, Les Malheurs de Sophie, it is noted that the mother is seated, holding the doll in her hands and with the eyes of the doll falling on her right hand. Sophie and Paul, his cousin, are in the foreground watching Madame De Réan's movements. This one is dressed in a long dress, with details on the bust and with the hair tidy with permanent. Sophie and the girls in the background are in plain dresses and Paul is in his shirt, coat, and pants. The kids are in an environment with rugs, curtains, and a table with notches. It is a scenario of an aristocratic place, with various details and posture of things and people. It is the representation of a class.

In Little Women, Mrs. March is the mother of the four sisters and it is up to her to guide her young daughters. When Margaret returns from a weekend with parties and luxury and is admired for her looks, the mother says,

This is perfectly natural and quite harmless if the taste does not become a passion and leads someone to do silly or modest things. Learn to know and value the praise, being worthy of it, and provoke the admiration of excellent people by being modest, as beautiful as Meg. (Alcott, 1880, p. 121)

The mother allows the young daughters to travel around the world and experience the possibilities offered there, such as theaters, lavish parties, as well as the forest and lakes. The cultural experience exists in the book, but what defends itself is the spiritual aspect, that is, the moral aspect. The return home allows the mother to direct her daughters and explain the world's issues, offering an element of discipline, understanding, and moral guidance to her daughters.

As regards religiosity, it is up to the family and especially the mother to guide and encourage children to perfect their spirituality their morality. In the Countess of Ségur's publications, they bring what is expected of the behavior of girls and the ways in which the characters and especially the protagonist Sophie need to learn to tame their passions and contain their movements. If the girl thinks she is smart enough to fool her mother and say that they were rats who ate the candied fruits in Les Malheurs de Sophie, she realizes her mistake in a dream at night. There was a beautiful garden full of flowers and fruit, separated by a railing, when trying to enter the garden, an angel appears that warns:

"Do not come in, Sophie, do not come from these fruits that look good, and that they are bitter and poisonous ... This is the garden of evil. Let me take you to the garden of good". "But", said Sophie, "the road ahead is rugged, full of stones, while the other is covered with fine, soft sand for the feet". "Yes", says the angel, "but the rough path will lead you into a garden of delights. The other will lead you to a place of suffering and sorrow; [...]". (Ségur, 1858, p. 157)

At first Sophie does not pay attention to the words of the angel, but when entering the beautiful garden, she soon realizes that nothing is so perfumed and appetizing. She remembers the angel and finds him at the edge of the garden. He takes her along the rocky road: "The first steps seemed difficult to him, but the more he advanced, the road became softer and the air seemed fresh and pleasant to him” (Ségur, 1858, p. 159). After the dream, the girl decides to tell her mother that she has eaten all candied fruits:

When she arrives in her mother's bedroom, she finds her face a little stern; but the dream reminds her of the candied fruit, and she begins to tell him everything immediately.

THE MOM

You know what that might mean, Sophie! That God, who sees that you are not sensible, warns by means of this dream, that if you continue to do everything that is bad and that you think pleasant, you will have sorrows instead of pleasures. (Ségur, 1858, pp. 159-160) 


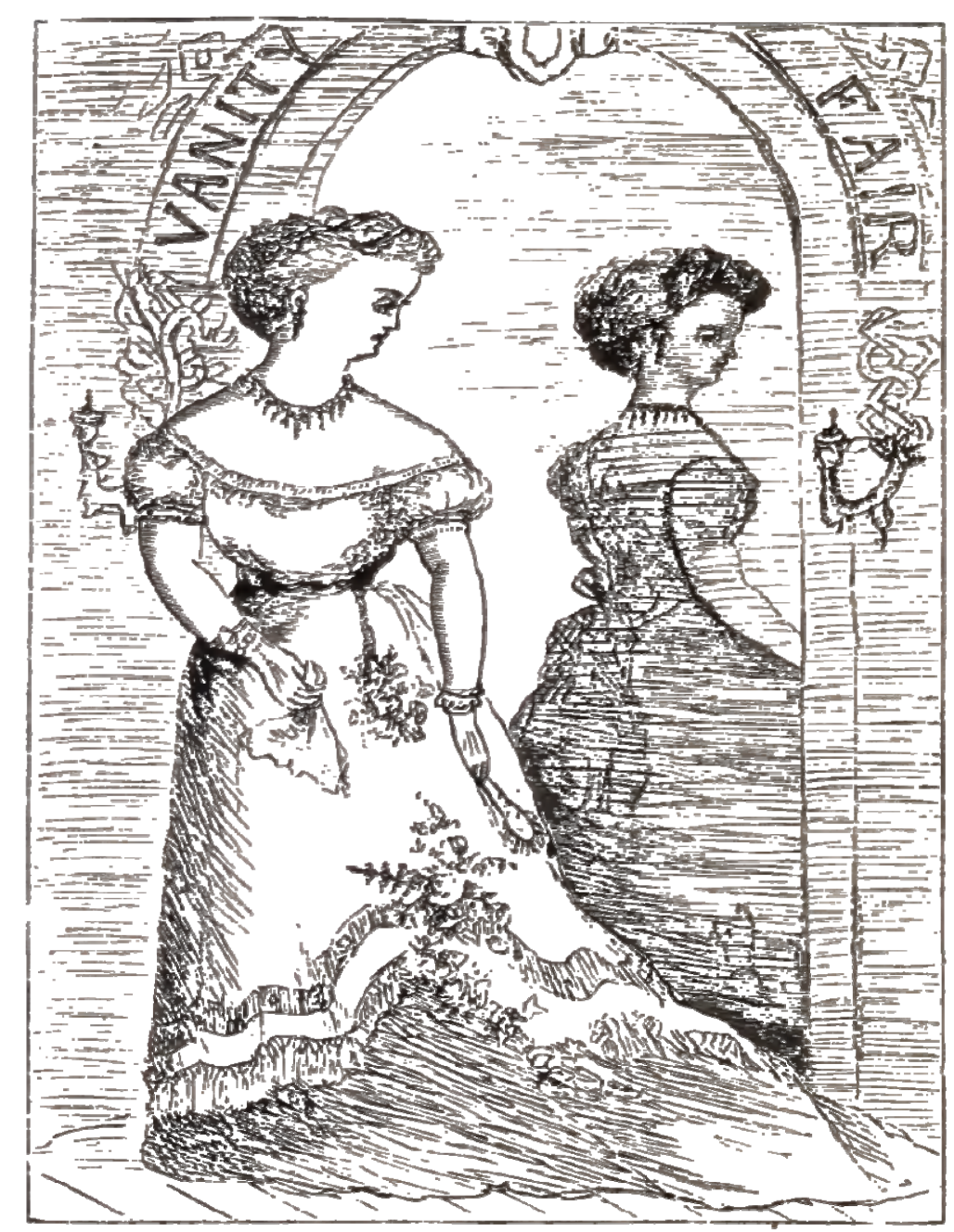

For several minutes, she stond like the jackdaw in the fable, enjoying her borrowel plumes. - I'Akk 135.

Figure 2. Little Women, 1868, p. 136, by May Alcott.

Religiousness, represented by an omnipresent God, assists in the guidance of the child, who is naive and has ideas that can be harmful. The idea of good and evil is present once again. Religiousness imposes its rules, indicating the ways considered good for the child to be obedient. The dream represents the belief in the reward of coming to a garden full of fruits and flowers after a hard walk.

Being greedy and wanting to fool adults is presented in the narrative as undesirable, since gluttony and lies would not be suitable for girls. For this reason, the angel of the dream recalls that this would not be a solution. The discourse of Les Malheurs de Sophie suggests that it is preferable to tell the truth. Childhood learns through religiosity what is desirable, morally correct and that it cannot lie or hide its errors before God and his family.

The illustration shows Sophie is pulled by the angel, who seeks to take the child away from the garden in which the trees and flowers would perish to be beautiful and appetizing, but that deceived the vision. Sophie still looks back doubtfully if it would not be better to walk the easy way, while the angel shows the other side. 
The image is true to the story told in the book, indicating a doubt raised by the protagonist when she comes across a beautiful garden.

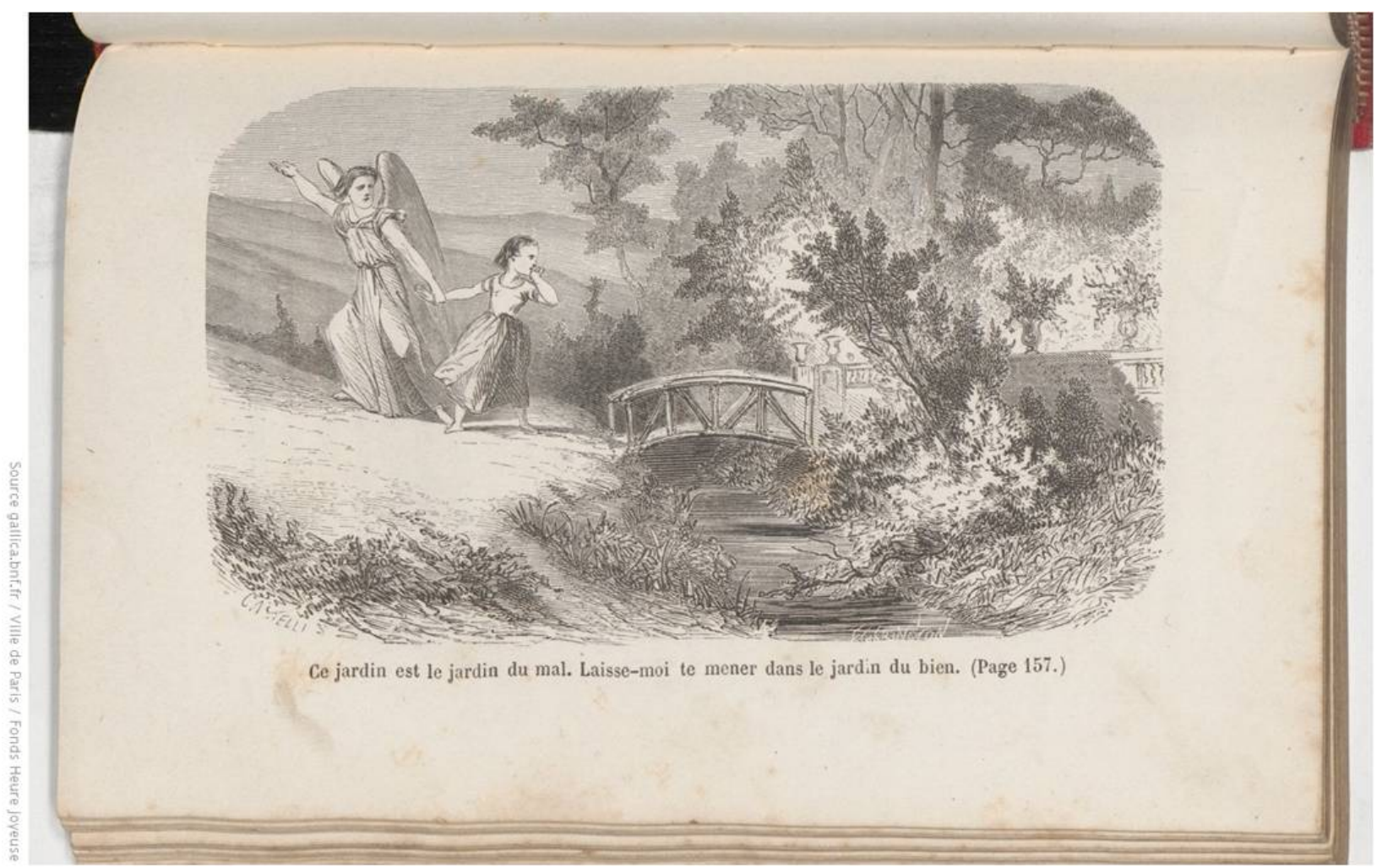

Figure 3. Les Malheurs de Sophie, 1858, p. 155, by Horace Castelli.

On the other hand, in the school the religiosity can also be present. In Clarita no Colégio, the school space is permeated by the catholic religion, with priests who do masses in the chapel and with activities directed towards the religion. The principal looks after the well-being of the students, whose parents have entrusted the school to learn. In more serious cases, it is up to the director to decide on other punishments. Clarita was once troubled by the comment of the French teacher, Mademoiselle Lenoir, who said that Brazilians "are lazy and without intelligence" (Violeta Maria, 1945, p. 92). So, during a recess where Clarita was playing catch, Mademoiselle Lenoir caught the attention of the girl, even reaching to hold her arm. Clarita, in this case:

[...] Feels as if one where of fire invade the heart to him ... and, not holding back, it explodes indignantly:

"I'm not, no, ma'am!" I have education! The lady who is ill to say that Brazilians do not have intelligence. Come eat our beans and speak ill of us! (Violeta Maria, 1945, p. 94)

Dona Emilia, for expressing her opinion in a crude way, imposes on the girl various punishments. She receives a zero for behavior in the report, stays incommunicado for three days separated from other children, and attends classes in silence, going without playing with the other girls during recess, beyond three months without visits, and for six months without leaving school with the family. When the director reminds her of the sadness that her parents would feel when she learned what the girl had done, Clarita burst into tears: "Thick and copious tears come down from her eyes... and gradually penetrate her heart, extinguishing the fire that devoured him, calming the anger that hardened him" (Violeta Maria, 1945, p. 97). 
Clarita remained incommunicable for several days and when she could stay in the recess, but without playing, she asks Our Lady to receive the grace to stay in the recess with her colleagues. When her uncles go to school to visit the children, Clarita remembers the punishment and warns the teacher that she is in the director's place. When the headmistress returns and learns of the case, she is pleased to see that Clarita had a "straight conscience" (Violeta Maria, 1945, p. 104) and forgives the girl's punishment.

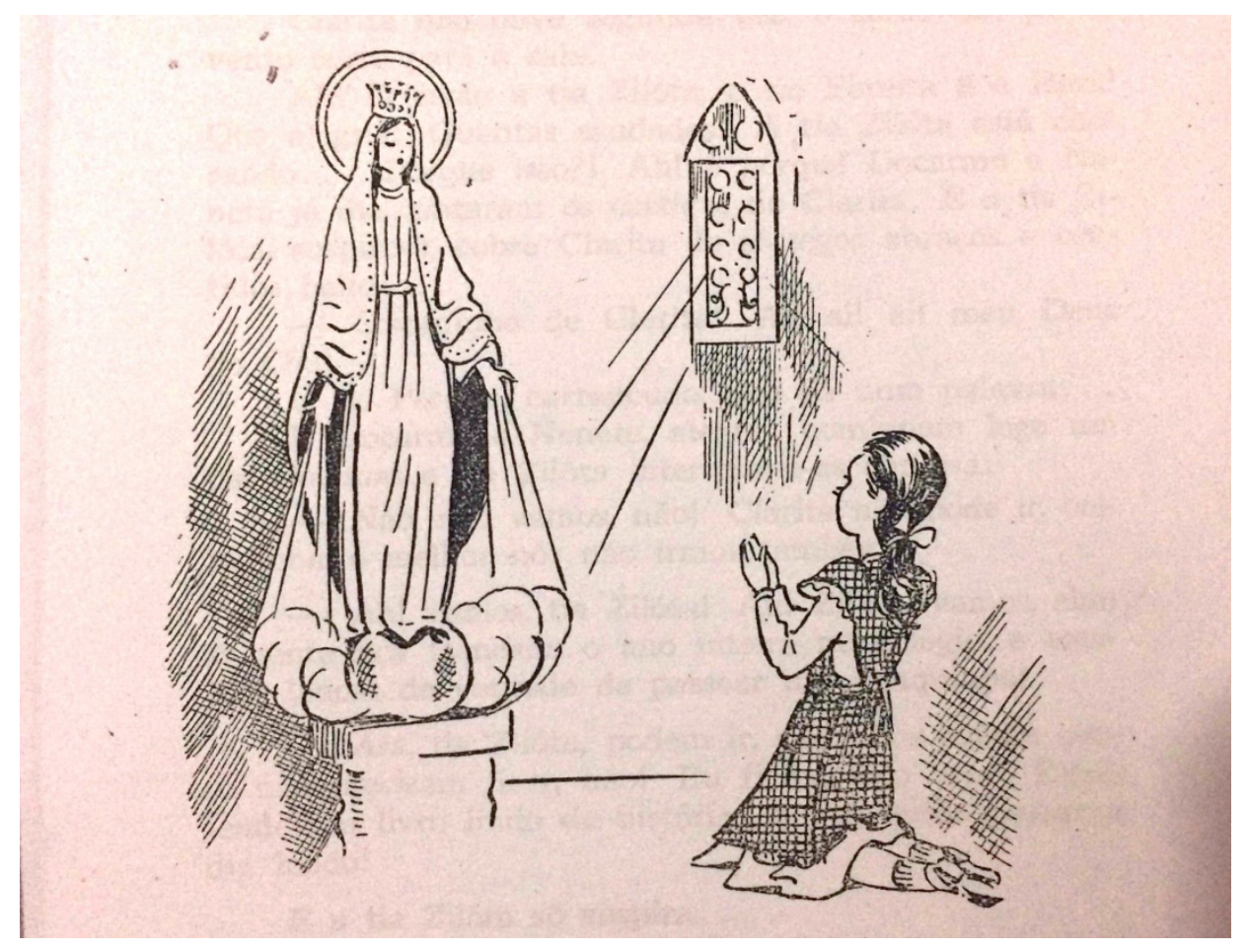

Figure 4. Clarita no Colégio, 1945, p. 99, by Manolo.

In the illustration, Clarita is kneeling asking Our Lady to ask Jesus to free her punishments. The image of the saint seems illuminated by the window of the chapel and seems larger than Clarita too. Devotion is greater for the child who needs to be mentored and sometimes even punished.

However, it is not only through the religiosity that children learn in narratives, and education permeates texts as well. Reflections on the representation of education are based on the notions of school form and know-how, coined by Vincent, Lahire, \& Thin (2001, p. 11). According to these authors, the school form is characterized by the relationship between a "teacher" (adult) and a "student" (infant), subject to a set of impersonal rules. This form emerges during modernity and deepens in societies of written culture, "[...] certain knowledges that have gained coherence in writing" (Vincent, Lahire, \& Thin, 2001, p. 29). This is also the moment when the very conception of childhood and its relation to the family are being established. The school form, therefore, is within a process, accompanied by a space and a demarcation of a specific time for learning (a time of life, an annual calendar, and daily schedules) and relates to other social forms, especially the political form, since it is linked to the exercise of power.

The school form is a form of socialization that, in the midst of resistance and difficulties, ends up imposing itself to other forms of socialization. In relation to the family, the school form differs, for " [...] the teacher is no longer a craftsman 'conveying' the know-how to a young person" (Vincent, Lahire , \& Thin, 2001, 
p. 13). The teacher teaches the student, in a specific space, permeated by rules considered as impersonal, which define the times and activities at each moment.

In Little Women, there is no information about the formation of Josephine, the protagonist, in a school space, but in the first part of the book, Amy, the younger sister, attends school. However, the girl ends up being punished with cakes in her hands by her teacher, who forbade the distribution of candy in the classroom.

"Your hand, Mss. March!" was the only response she had received from his mute appeal, and, too proud to cry or plead, Amy clenched her teeth, threw her head back defiantly, and endured, without hesitation, several tingling strokes in her small palm. They were neither numerous nor heavy, but it made no difference to her. For the first time in her life she was beaten; and the disgrace in his eyes was as deep as if he had overthrown her. (Alcott, 1880, pp. 86-87)

"Young ladies, you remember what I said to you a week ago. I am sorry this has happened, but I never allow my rules to be infringed, and I never break my word. Miss March, hold out your hand."

Amy started, and put both hands behind her, turning on him an imploring look which pleaded for her better than the words she could not utter. She was rather a favorite with "old Davis," as, of course, he was called, and it's my private belief that he would have broken his word if the indignation of one irrepressible young lady had not found vent in a hiss. That hiss, faint as it was, irritated the irascible gentleman, and sealed the culprit's fate.

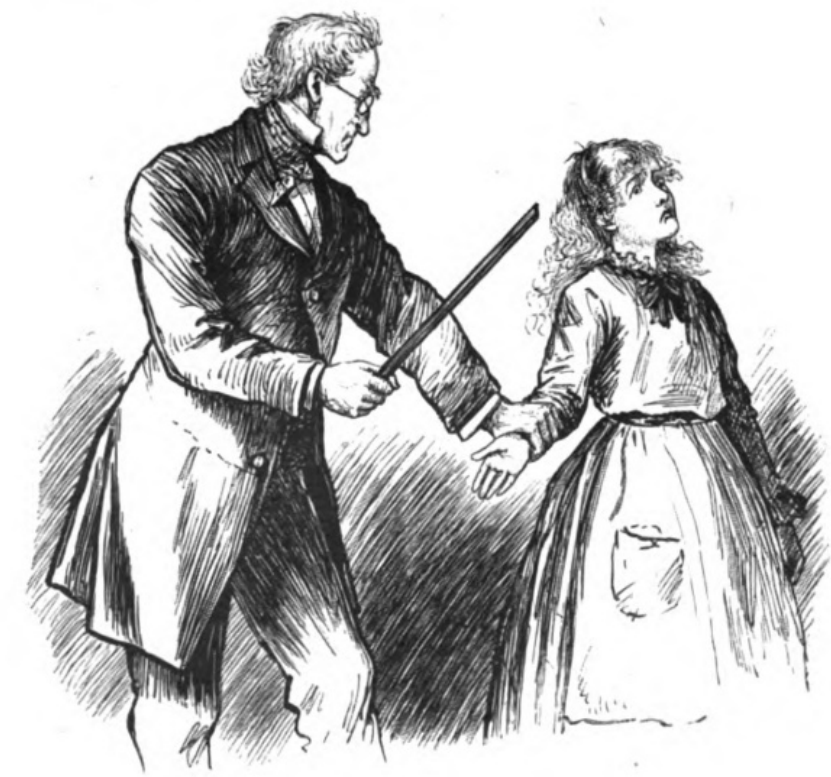

"Your hand, Miss March!" was the only answer her mute appeal riceived; and, too proud to cry or beseech, Amy set her teeth,
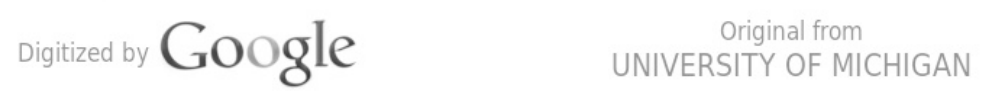

Figure 5. Little Women, 1880 p. 86, by Frank Thayer Merrill. 
In the illustration, the teacher holds Amy's hand about to use the ruler to hit her. The look on the teacher looks grave as the girl looks sadly and fearfully up. The image gives a sample of what it is to receive a physical punishment and how much this situation was no longer desired for the formation of childhood.

Physical punishment still existed at that time, as Michelle Perrot (2009) analyzed in the French case: "They are in school and in certain high schools pretending to impose military discipline" (p. 145). In the case of narrative, it is a girls' school and the teacher adopts extreme behavior in a specific case.

However, the family decides to remove the girl from school, as she does not accept that she has been punished in this way. The mother says:

I do not approve of corporal punishment, especially against girls. I do not like the way Mr. Davis teaches, and I think the girls you're joining do not do you any good, so I'll ask your father for advice before I send to some other place [of teaching]. (Alcott, 1880, p. 88)

Here the family protects individuals from the group, seeking to avoid physical aggression. It is noted that corporal punishment would not be adequate especially for girls, as they would be more fragile.

Different situation is found in the books of Maria Clarice Marinho Villac. On the other hand, in Clarita da pá Virada, the girl learns by the know-how, in the observation of the adults and in some school spaces frequented by her. In the school, the narrator describes some situations experienced in this space, interspersing with vacation moments in the grandfather's farms. Central figure in the text is Dona Emilia, the director of the school. It is she who guides and indicates the paths and the posture expected by the girls. The issue of obedience, charity, and good manners are essential issues of femininity in school.

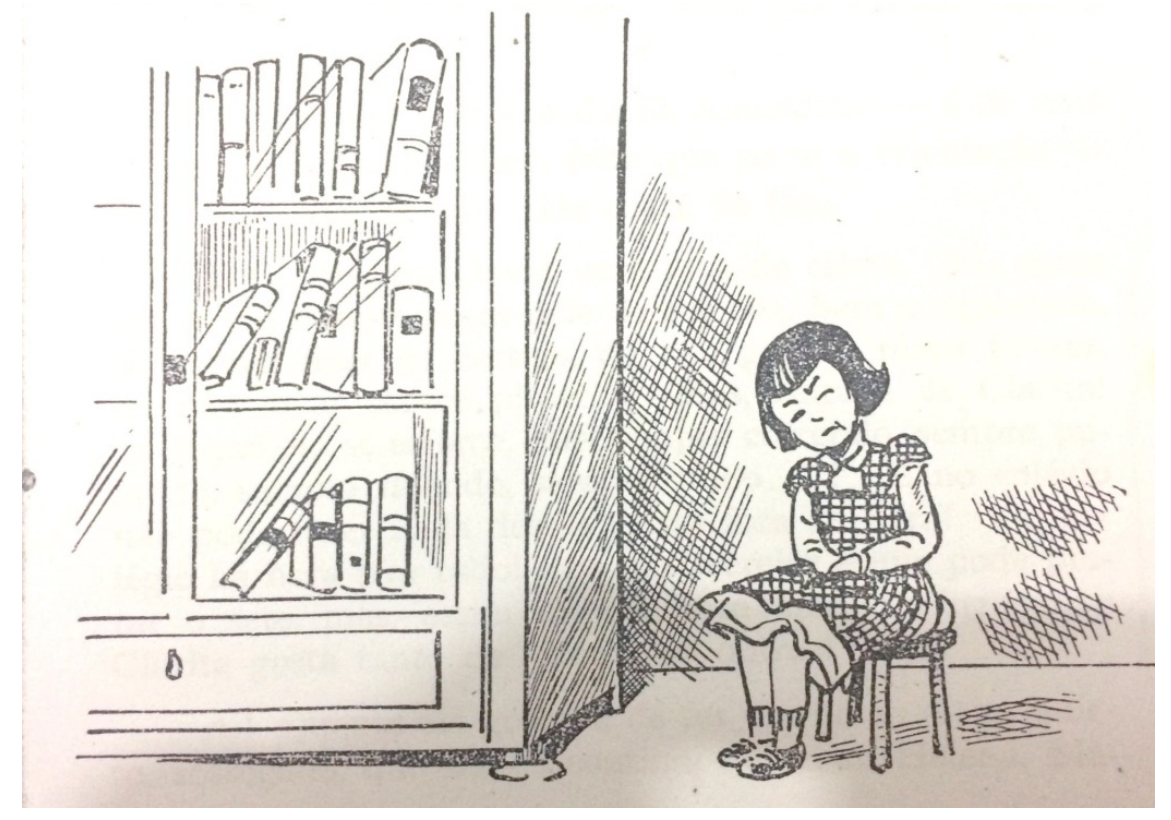

Figure 6. Clarita no Colégio, 1945, p. 27, by Manolo.

Dona Emilia tries to catch Clarita's attention by making her reflect on her mistakes and from her regret, as from the time she was coarse with her French teacher. However, from the beginning the girl already liked to do her tricks. At recess, Clarita was reading a letter sent by her father and runs off, running with the letter of the hand and shoving and shaking some children, without her sister, who leaves behind and can read the letter. 
When the teacher asks Clarita to deliver the letter to her sister, she reads that the family has gained a new brother and will be baptized by the uncles. In the queue to return to the classroom, Dona Emilia calls her to sit on the stool of her office: "Sit there on that stool. You're very excited, you need to calm down a bit" (Violeta Maria, 1945, p. 27)

In the illustration, there is the child sitting next to a closet full of books and glass doors, which protect objects that bring knowledge. It is an exemplary school, with different spaces for girls to live and study, with piano, geography, science rooms, as well as all experimental apparatus. The office does not leave out the knowledge and guidance that adults guard and offer to girls.

The text and illustrations presented throughout this work bring a sample of what exists in the books. They bring the representation of what is expected for the characters to the readers, by means of funny and reflective drawings that would aid in the reading. Each writer found different illustrators by the intervention of their editors and obtained publications that were spread around the world, bringing the representations of childhood in their relationship with family, education, and religiosity. These illustrations try to be faithful to the books, bringing in images what the text leaves more dispersed.

\section{Final Considerations}

Each writer had different experiences in different contexts. However, in the society in which they lived and traced their trajectories, institutions that turn to childhood, such as family, school, and churches or catechisms, were present as well as constituting the social imaginary, becoming social categories in the child's life that was under surveillance, care, and discipline.

The representations in their publications are constructed by approaching the themes, as layers that are overlapping, reiterating what would be desirable or what could be left aside. Such representations point to what would be most appropriate for childhood and what was advocated by some social groups, such as the aristocracy, the bourgeoisie, and the patriarchal aristocracy. These are commercial narratives, which seek to educate through representations that indicate what would be desired for the formation of childhood, and especially girls. It is a world in which girls and women have their place in the domestic sphere, preserving their innocence, without getting tainted in the public space.

As we know, such discourses were not only constructed by the writers, but also in the orientation of the editors and printers who transform the written sketch into a printed book, containing flashy covers, flowing and well-distributed texts along the pages, with formats suitable for the handling of readers and, eventually, illustrations selected to introduce themselves to children and young people.

In this context, the illustrations were commissioned to compose the narratives. They walk in tune with the text with images that bring the experience of girls with their mischief, daring, and rebelliousness and with many adults around to indicate a path indicated as desirable for them.

These narratives continue to be reprinted, indicating that the femininity of the time still echoes in the experiences of girls and young people of the 21 st century. The aspects of these books can be recognized or left aside, and it is up to the readers to read between the lines and make their choices.

\section{References}

Alcott, L. M. (1880). Little women or Meg, Jo, Beth and Amy. Boston: Roberts Brothers. Retrieved December 12, 2015 from https://babel.hathitrust.org/cgi/pt?id=mdp.39015004168533;view=1 up;seq=9 
Alcott, L. M. (2006) . Little women/good wives. Londres: Wordworth Editions.

Castoriadis, C. (1982). A instituição imaginária da sociedade. Rio de Janeiro, RJ: Paz e Terra.

Chartier, R. (1991). Mundo como representação. Estudos Avançados, 5(11), 173-191. São Paulo: Instituto de Estudos Avançados da Universidade de São Paulo.

Chartier, R. (2002a). Capítulo IV: Textos, impressos, leituras. In A história cultural: Entre práticas e representações. Lisboa, Portugal: DIFEL.

Chartier, R. (2002b). À beira da falésia: A história entre incertezas e inquietude. Porto Alegre, RS: Editora Universidade.

Perrot, M. (Org.). (2009). História da vida privada: Da revolução Francesa à primeira guerra. São Paulo, SP: Companhia das Letras.

Ségur, C. (1858). Les petites filles modèles. Paris: Hachette. Retrieved November 25, 2015 from http://gallica.bnf.fr/ark:/12148/bpt6k6513581s

Ségur, C. (1861). Les vacances. Paris: Hachette. Retrieved November 25, 2015 from http://gallica.bnf.fr/ark:/12148/bpt6k6577519b/f7.image

Ségur, C. (1880). Les malheurs de Sophie. Paris: Hachette. Retrieved November 25, 2015 from http://gallica.bnf.fr/ark:/12148/bpt6k6577498m/f7.image

Vincent, G., Lahire, B., \& Thin, D. (2001). Sobre a história e a teoria da forma escolar. In Educação em Revista. Belo Horizonte, n. 33, p. 7-47.

Violeta Maria, M. C. (1939) ${ }^{5}$. Clarita da pá virada. São Paulo: Revista dos Tribunais.

Violeta Maria, M. C. (1945). Clarita no colégio. São Paulo: Cristo-Rei.

${ }^{5}$ Work found in the Hans Christian Andersen Municipal Library, in São Paulo (SP). 